\title{
TTR
}

Traduction, terminologie, re?daction

\section{Anuradha Dingwaney and Carol Maier, ed. Between Languages and Cultures. Translation and Cross-cultural Texts. Pittsburgh and London, University of Pittsburgh Press, 1995, 359 p.}

\section{Sherry Simon}

Volume 9, numéro 2, 2e semestre 1996

Parcours de traduction

Pathways of Translation

URI : https://id.erudit.org/iderudit/037272ar

DOI : https://doi.org/10.7202/037272ar

Aller au sommaire du numéro

Éditeur(s)

Association canadienne de traductologie

ISSN

0835-8443 (imprimé)

1708-2188 (numérique)

Découvrir la revue

Citer ce compte rendu

Simon, S. (1996). Compte rendu de [Anuradha Dingwaney and Carol Maier, ed. Between Languages and Cultures. Translation and Cross-cultural Texts. Pittsburgh and London, University of Pittsburgh Press, 1995, 359 p.] TTR, 9(2), 246-248. https://doi.org/10.7202/037272ar

Tous droits réservés @ C TTR: traduction, terminologie, rédaction — Les auteurs, 1996
Ce document est protégé par la loi sur le droit d'auteur. L’utilisation des services d'Érudit (y compris la reproduction) est assujettie à sa politique d'utilisation que vous pouvez consulter en ligne.

https://apropos.erudit.org/fr/usagers/politique-dutilisation/ 


\section{Anuradha Dingwaney and Carol Maier, ed. Between Languages and Cultures. Translation and Cross-cultural Texts. Pittsburgh and London, University of Pittsburgh Press, 1995, 359 p.}

This volume takes up a timely challenge: how to bring translation issues back into the study of cross-cultural literary contact. Such an effort should seem superfluous in a context which has seen the development of contemporary transnational cultural studies. Unfortunately, it is not. While the study of European literatures has traditionally required the learning of national languages and a critical understanding of the conditions under which translations are produced, it would seem that the opening of the globe to cultural studies has not generated the same sorts of requirements. Cultural exchange is carried out under the quasiexclusive aegis of the English language, with little concem being shown for the linguistic ground from which Third World literature has sprung.

This substantial volume is an exciting but somewhat unwieldy collection of essays devoted to language issues as they are played out in contemporary cross-cultural encounters. The volume is divided into five sections. "Translators on Translating Across Cultures" combines an introductory theoretical essay by Carol Maier with three accounts by translators of the issues involved in their work. Rosario Ferré, a Puerto Rican writer, describes her writing as a practice of translation; Sharon Masingale Bell explains why she translated the "creole" in a text by the Haitian writer, J.-S. Alexis, by expressions from Black English; Agha Shahid Ali discusses the political and cultural issues in translating the Urdu ghazals of Faiz Ahmed Faiz.

The second section of the volume entitled "On (Not) Translating Cultures" focuses on those moments when translation is impeded by adverse cultural forces. Edward Said piece deals with the 
virtual embargo on translations from Arabic in the Anglo-American publishing world. Those works which are available in translation are largely ignored, doing nothing to bridge the cultural abyss which looms between Arabs and the West. There is not much coherence among the four pieces which follow, which speak in different ways of the portrayal of otherness in literature. One wonders why Timothy Brennan's piece on C.L.R. James was included in this anthology.

The third section, "Examining Translations and Cross-Cultural Encounters" includes excellent pieces by Indira Karamcheti on Aimé Césaire, Harsha Ram on the translation of Russian poetry and Mary Layoun on two Lebanese texts. The penultimate section deals with issues of pedagogy, while the final responses are by Talal Asad and James Boyd White.

The exploratory nature of this volume accounts for some of its difficulty in delimiting its subject. Translation is given a rather wide meaning, including the process of writing between languages. The somewhat blurred focus is justified in the current state of thinking in postcolonial literary studies and in translation studies. There is an acute sense of the importance of investigating the in-between space of translation as it negotiates between the historically charged realities of former metropolis and colony, but there is often real difficulty in identifying the real effects and implications of translations. Subversion or collusion? Original contribution or simple act of mediation? These are complex issues which, as Talal Asad points out in his concluding remarks, need to be addressed with rigour. Asad argues forcefully for the distinction between critique and translation. Although one can argue about the original, you can't argue with it, he says. At the same time, this distinction does not take account of the many displacements which occur through the process of translation.

This volume is a vital contribution to the current state of thinking about linguistic and cultural exchange. It indicates the direction which translation studies will be taking in the years to come. The book would have been more effective, I think, had the collection been tighter and the theoretical framework more focused. The emphasis on pedagogy, on the other hand, is refreshing and stimulating. The editors readily speak in the first person, emphasizing the politically problematic 
nature of the space 'between' as well as its creative possibilities. Their collective essay explains that they came to their topic out of their experience as teachers of Third World literature. Their book, like their teaching, tries to establish new kinds of connections between translation, teaching, writing, and the daily experience of living in the gap between cultures. As an indication of the current state of thinking in crosscultural literary studies and as a promise of what is yet to come, Between Languages and Cultures is an important publication.

Sherry Simon Concordia University 